\title{
Reflections on the Scholarship of Teaching and Learning
}

\author{
Richard L. Miller, PhD \\ Professor and Chair, Department of Psychology \\ University of Nebraska at Kearney
}

In his 1854 essay "The Idea of a University," John Henry Newman suggested that the primary purpose of the university is education: "a place for the communication and circulation of thought," a place where "one generation forms another." He contended that to discover and to teach were distinct functions and that "those who spend their time dispensing existing knowledge are unlikely to have the leisure or energy to acquire new" (p. 10).

In contrast, D. W. Hamlyn, in his commentary entitled "The Concept of a University," proposed that one of the enduring achievements of universities, dating back to the Middle Ages, was the scholarship of discovery: "If learning is to be pursued and if knowledge is to be enlarged there have to be institutions like universities, which have the double role of pushing back the frontiers of knowledge and of enabling future generations to carry on that process" (1996, p. 216).

At today's university the commitment to both scholarship and teaching seems incontrovertible. It is enshrined in mission statements, strategic plans, and promotion and tenure guidelines. This recognition of the University's dual purpose has led to an unfortunate division between teaching and research; a division recognized by the meta-analysis of 58 studies conducted by Hattie and Marsh (1996) that found no relationship between research productivity and teaching effectiveness. Their recommendation was that universities should aim to increase the circumstances where teaching and research meet.

How can this be done? In his landmark work, Scholarship Reconsidered: Priorities of the Professoriate, Ernest Boyer (1996) broadened the traditional definition of scholarship to include four distinct types of scholarship: the scholarship of discovery, the scholarship of integration, the scholarship of application, and the

Teaching is undervalued at the academy, not because colleges and universities don't care about teaching, but because what and how we teach is not generally shared with a community of scholars. scholarship of teaching and learning.

The scholarship of teaching and learning is an academic endeavor that, until recently, many faculty members at research oriented institutions could not have undertaken and still attain tenure. As Lee Schulman (1993) suggested in a foundational essay entitled "Teaching as Community Property: Putting an End to Pedagogical Solitude," teaching is undervalued at the academy, not because colleges and universities don't care about teaching, but because what and how we teach is not generally shared with a community of scholars. He called for reconnecting teaching to the disciplinary communities in which teachers conduct their scholarship, thus making pedagogical issues available for peer review and reflection. Since that time, the scholarly investigation of teaching and learning has grown in its reputation as a bona fide field of inquiry (Hutchings \& Schulman, 1999). For us at the academy, the basis for researchable questions is rooted in everyday experience; the realization that Parker Palmer articulated, after twenty years of teaching, that he would "never master this baffling vocation" (1999, p. 9).

Most college and university faculty spend much of their time and energy teaching, and most take teaching seriously, often asking questions about how and why students do or do not learn. In fact, teaching imperfections can form the grist for our collective mill in formulating hypotheses about pedagogical scholarship. For example, within any discipline, we might examine innovative ways of integrating

InSight: A Journal of Scholarly Teaching 
information that stimulate students' intellectual curiosity. The innovation could be a new way of combining two topics, a new technology that accelerates learning or makes transfer more probable, or a framework for integrating seemingly diverse concepts. The challenge is to ground our teaching in a theoretical framework and to base our approaches on empirical evidence that addresses how students learn when exposed to different pedagogical approaches. Pat Hutchings (1999) of The Carnegie Academy for the Scholarship of Teaching and Learning (CASTL) has suggested that the desired outcomes of this endeavor should be a scholarly body of work that:

1. fosters significant, long-lasting learning for all students;

2. enhances the practice and profession of teaching; and

3. brings to faculty's work as teachers the recognition and reward afforded to other forms of scholarly work.

With these goals in mind, the scholarship of teaching and learning can examine a number of basic questions. Perhaps one of the most basic questions concerns how students learn. Some unanswered questions about the learning process include: How can teachers promote self-regulated learning, what techniques can be used to reduce anxiety and other barriers to learning, what concepts are most readily understood using experiential techniques, and what practices promote learning autonomy?

A second major area addressed by the scholarship of teaching and learning is the effectiveness of different teaching approaches. Some issues with unanswered questions include the value of collaborative learning, the use of technology in the teaching/learning process, techniques for building rapport and the importance of rapport on student outcomes, the use of Gestalt teaching techniques, or the effectiveness of analogy-enhanced teaching.

Curriculum development can also be

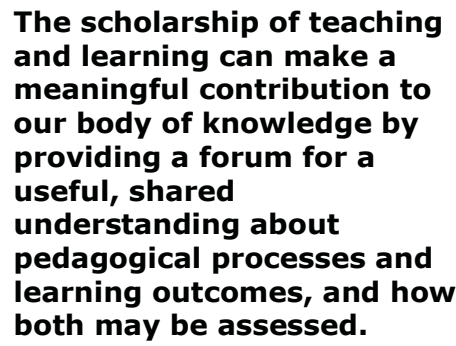

The scholarship of teaching and learning can make a meaningful contribution to our body of knowledge by providing a forum for a useful, shared understanding about pedagogical processes and learning outcomes, and how both may be assessed. informed by the scholarship of teaching and learning. The use of scaffolding, the value of rubrics, how our teaching relates to Bloom's taxonomy and the use of interdisciplinary approaches to teaching are all issues that can be informed by research.

As one final example, the approaches that we take to the process of assessment can be enhanced by the scholarship of teaching and learning. While many faculty remain skeptical about external mandates for assessment, the process can focus on important questions that can make a real difference in the teaching/learning process including: how students learn to think critically within the context of a discipline, what approaches assist students in making ethical decisions, and how students learn what has been called the "covert" curriculum.

According to Aristotle, "teaching is the highest form of understanding." The scholarship of teaching and learning provides an opportunity for faculty across disciplines to share that understanding by engaging in serious intellectual work. Thus, the scholarship of teaching and learning can make a meaningful contribution to our body of knowledge by providing a forum for a useful, shared understanding about pedagogical processes and learning outcomes, and how both may be assessed.

\section{References}

Boyer, E. L. (1990). Scholarship reconsidered: Priorities of the professoriate. Princeton, NJ: Carnegie Foundation for the Advancement of Teaching.
Hamlyn, D. W. (1996). The concept of a university. Philosophy, 71, 205218. 
Hattie, J., \& Marsh, H. W. (1996). The relationship between research and teaching: A meta-analysis. Review of Educational Research, 66(4), 507-542.

Hutchings, P., \& Schulman, L. S. (1999, September/October). The scholarship of teaching: New elaborations, new developments. Change, 11-15.
Palmer, P. J. (1999). The courage to teach: Exploring the inner landscape of a teacher's life. San Francisco: Jossey-Bass.

Newman, J. H. (1990). The idea of a university. South Bend, IN:

University of Notre Dame Press.

(Original work published in 1854)

Schulman, L. S. (1993, November). Teaching as community property:

Putting an end to pedagogical solitude. Change, 6-7.

Rick Miller received his PhD in 1975 from Northwestern University. He has taught at Georgetown University, the University of Cologne, and is currently chair of the Psychology Department at the University of Nebraska at Kearney. He served for many years as the Director of applied behavioral science research projects for the Human Resources Research Organization (HumRRO) in Heidelberg, Germany. He is a recipient of the University of Nebraska system award for "Outstanding Teaching and Instructional Creativity" and the Pratt-Heins Foundation Award for Scholarship. Under his leadership, the Department of Psychology was awarded the 1999 Outstanding Teaching Department Award from the University of Nebraska. 